\title{
TECHNIQUE FOR INCREASING THE ANTENNA GAIN-TO-NOISE-TEMPERATURE OF SATELLITE COMMUNICATIONS EARTH STATIONS WITH AXISYMMETRIC REFLECTORS
}

DOI: $|0.36724 / 2072-8735-2020-| 4-2-45-5 \mid$

Pavel A. Titovets,

Moscow Technical University of Communications

and Informatics, Moscow, Russia,

paveltitovec@mail.ru
Keywords: satellite communication, earth station; axisymmetric reflector antennas; antenna gain-to-noisetemperature, signal-to-noise ratio enhancement technique.

\begin{abstract}
Satellite communications for many sparsely populated, inaccessible and remote areas, especially the Arctic regions and the Far North is the main form of communication. When organizing communication, it is required to receive signals with the highest possible signal-to-noise ratio. In satellite earth stations, axisymmetric reflector antennas are mainly used. In these areas, the angle of the antennas to the horizon does not exceed 20 degrees. There are problems in receiving signals at angles of inclination of axisymmetric reflector antennas to the horizon, not exceeding 20 degrees, by satellite earth stations. These problems are related to the signal-to-noise ratio at the output of the antennas. At such angles of inclination of the reflector antennas to the horizon, thermal radio emission from the Earth's surface has a significant negative effect on the received signals. This radio emission increases the noise level and reduces the signal-to-noise ratio at the output of the antenna. To reduce thermal radio emission received by reflector antennas from the Earth's surface and increase the signal-to-noise ratio at the output of the antennas, a technique has been developed to increase the antenna gain-to-noise-temperature. This technique consists of three independent methods for increasing the antenna gain-to-noise-temperature, which can be used separately. For the convenience of choosing from existing methods for increasing the antenna gain-to-noise-temperature, the methodology takes into account the features of applicability of these methods for specific antennas. The developed method for calculating antenna gain-to-noise-temperature is described, which allows one to theoretically evaluate changes in antenna gain-to-noise-temperature due to open screens on the reflector and counter-reflector, as well as through the use of antenna feeds with an asymmetric radiation pattern.
\end{abstract}

Information about author:

Pavel Alexandrovich Titovets, leading engineer of the research department Moscow Technical University of Communications and Informatics Moscow, Russia

\footnotetext{
Для цитирования:

Титовеи, П.А. Методика повышения шумовой добротности осесимметричных зеркальных антенн земных станций спутниковой связи // T-Comm: Телекоммуникации и транспорт. 2020. Том I4. №2. С. 45-5I.

For citation:

Titovets P.A. (2020) Technique for increasing the antenna gain-to-noise-temperature of satellite communications earth stations with axisymmetric reflectors. T-Comm, vol. 14, no.2, Pp. 45-5I. (in Russian)
} 


\section{Introduction}

There are situations when, when receiving signals from satellite transponders of satellite communication systems located in a geostationary orbit, the signal-to-noise ratio (SNR) is not enough to demodulate signals with minimal requirements. There are also situations when the SNR of signals provides a minimum information transfer rate, and to increase the information transfer rate, an increase in the SNR at the antenna output is required. In these situations, it is necessary to modernize the receiving path with axisymmetric reflector antennas.

Reception of signals from satellite transponders located in a geostationary orbit is carried out mainly on axisymmetric reflector antennas of satellite communications earth stations. These antennas should receive signals with the highest possible SNR. For this, an antenna reflector with a diameter of 2 meters with a horn feed or a feed in the form of the open end of a circular waveguide is used. Such antennas are mainly constructed according to the axisymmetric single-reflector scheme or the axisymmetric two-reflector Cass egrain scheme. They include a reflector and a counter-reflector with an antenna feed, a waveguide path and a low-noise amplifier-converter, and a slewing ring [1].

A characteristic that determines the SNR of signals at the antenna input at various angles of its inclination to the horizon is the antenna gain-to-noise-temperature $\left(\frac{G}{T}\right)$ [2]. One of the options for increasing SNR at the output of reflector antennas is the use of methods to increase the antenna gain-to-noise-temperature $[3 ; 4 ; 5]$. Each method has features of application and use. In this article, the developed methods are combined into one technique that can be used for any axisymmetric reflector antenna of a satellite communications earth station.

The technique of increasing the antenna gain-to-noisetemperature with axisymmetric reflector.

The technique consists of the following sequence of actions:

1. The following are determined from the technical documentation of the antenna: construction scheme, basic geometric parameters, attenuation or composition and lengths of the elements of the waveguide path and the range of received frequencies. The main geometric parameters of the antenna: reflector diameter $\left(D_{R}\right)$; diameter of the counter-reflector $\left(D_{C}\right)$; reflector opening angle $\left(2 \psi_{0}\right)$; counter-reflector opening angle $\left(2 \varphi_{0}\right)$; the maximum and minimum angles of inclination of the antenna to the horizon $\left(\alpha_{\max }\right.$ and $\left.\alpha_{\min }\right)$ at which signals can be received at the installation site of the reflector antenna.

2. The value of the antenna gain-to-noise-temperature is measured. If these measurements are not possible, the SNR values of the signals periodically transmitted with a constant level are measured (the signals of the radio beacons of satellite transmitters can be used as such signals).

3. The organizational and technical capabilities of installing screens on a single-reflector reflector or a two-reflector antenna counter-reflector are determined, depending on its layout. If it is possible to install a screen on a single-reflector antenna, points 8-15 of this methodology are not fulfilled; on a tworeflector antenna, points 4-7 and 12-15 of this methodology are not fulfilled. If it is not possible to install screens, paragraphs 411 of this procedure are not performed.
4. The theoretical dependence of increasing the antenna gain-to-noise-temperature $\left(\frac{G}{T}\left(\alpha, \beta_{R}, F_{A F}(\psi)\right)-\frac{G}{T}\left(\alpha, 0, F_{A F}(\psi)\right)\right)$ on the angle of reflector shielding is determined $\left(\beta_{R}\right)$.

5. The value of the screening angle of the reflector is determined from the obtained dependence in paragraph 4 by the criterion of maximum expression (1).

6. The geometric parameters of the screen are determined (Figure 3 ) at the value of the reflector screen angle defined in paragraph 5: screen depth $\left(R_{R}\right)$, expression (16); screen opening angle $(\tau)$; perimeter length $\left(L_{P}\right)$, expression (17). From the dependence of the screen depth on the solution angle $\left[R_{R}(\tau)\right]$, expression (16), the value of the solution angle is determined at which the screen depth is minimal. The angle of the screen determines the shape of the screen if $\tau=0$ the screen has a cylindrical shape, and if it $\tau>0$ is conical.

7. An open screen is made (based on the parameters calculated in paragraph 6 of this method) and is installed along the lower edge of the reflector.

8. The theoretical dependence of increasing the antenna gain-to-noise-temperature

$\left(\frac{G}{T}\left(\alpha, \beta_{C}, 0, F_{A F}(\theta)\right)-\frac{G}{T}\left(\alpha, 0,0, F_{A F}(\theta)\right)\right)$ on the screen angle of the counter-reflector $\left(\beta_{C}\right)$ is determined.

9. From the obtained dependence in paragraph 8 , the value of the screening angle of the counter-reflector is determined by the criterion of maximum expression (2).

10. The geometric parameters of an unclosed screen are determined based on the value $\beta_{C}$ (Figure 4): screen depth $\left(R_{C}\right)$ expression (18); perimeter lengths $\left(L_{C}\right)$, expression (19). The angle of the conical surface of the screen is equal to half th $\epsilon$ opening angle of the reflector. At this angle of the solution, the conical surface of the screen provides the maximum screening angle of the counter-reflector.

11. An open conical screen is made (based on the parameters calculated in paragraph 10 of this method) and installed on the bottom of the counter-reflector (Figure 4).

12. An antenna feed is selected that provides an asymmetric radiation pattern and an increase in the antenna gain-to-noisetemperature according to the criterion of the maximum of expressions (1) or (2) depending on its construction scheme. When choosing an antenna feed, the shape of the radiation pattern must be taken into account. If it is impossible to replace the standard antenna feed, it is necessary to change the geometric shape of the feed. Computer simulation tools such as ANSYS HFSS, CST STUDIO SUITE Antenna Magus or the like are used to determine the geometric shape of the antenna feed, which provides an increase in the antenna gain-to-noise-temperature.

13. The theoretical value of increas ing the antenna gain-tonoise-temperature is determined using an antenna feed with an asymmetric radiation pattern $\left(F_{A A F}(\psi)\right)$ and a standard antenna feed $\left(F_{A F}(\psi)\right)$. The calculation $\frac{G}{T}\left(\alpha, 0, F_{A F}(\psi)\right)$ and $\frac{G}{T}\left(\alpha, 0, F_{A F}(\psi)\right)$ is made from expressions (1-15) taking into account the asymmetry $F_{A A F}(\psi)$, while the angles, $\beta_{R}=0 \quad \beta_{C}=0$. If the radiation 
1. pattern of the antenna feed is not known, then it is determined from expression (8)

2. An antenna feed with an asymmetric radiation pattern is selected that provides the maximum value of the theoretical increase in the antenna gain-to-noise-temperature.

3. The regular antenna feed is replaced with an antenna feed with an asymmetric radiation pattern (or the geometric shape of the standard antenna antenna feed is changing).

4. The measurement is carried out at the same value as in paragraph 2 of this methodology.

5. The value of increasing the antenna gain-to-noisetemperature is determined (as the difference in the values of the antenna gain-to-noise-temperature or SNR signals measured in paragraphs 7 and 2).

\section{Method for calculating the antenna}

\section{gain-to-noise-temperature}

A method has been developed for calculating the antenna gain-to-noise-temperature taking into account the effect of screens on the reflector and counter-reflector. Using this method, one can determine the change in the gain to the noise temperature of reflector antennas depending on the shape of the asymmetric radiation pattern of the antenna feed.

Expressions for calculating the antenna gain-to-noisetemperature of a single-reflector antenna

$$
\frac{G}{T}\left(\alpha, \beta_{R}, F_{A F}(\psi)\right)=10 \lg \left(\frac{\pi^{2} \eta_{W} \eta_{S} \eta_{R} v D_{R}^{2}}{\lambda^{2} T_{S R A}\left(\alpha, \beta_{R}, F_{A F}(\psi)\right)}\right),
$$

and two-reflector antennas

$$
\frac{G}{T}\left(\alpha, \beta_{C}, F_{A F}(\theta)\right)=10 \lg \left(\frac{\pi^{2} \eta_{W} \eta_{S}\left(\beta_{C}\right) \eta_{R} \eta_{C} v D_{R}{ }^{2}}{\lambda^{2} T\left(\alpha, \beta_{C}, F_{A F}(\theta)\right)}\right),
$$

where $\eta_{S}\left(\beta_{C}\right) ; \eta_{R} ; \eta_{C} ; \eta_{W}$ is the power transmission coefficients of the signal, taking into account the shadowing of the reflector by the antenna design elements, from the antenna feed for a single-reflector or antenna feed and the counter-reflector for a tworeflector antenna to the reflector, from the antenna feed to the counter-reflector of the antenna, waveguide, respectively; $v$ ? coefficient of use of the reflector surface; $\lambda$ ? wavelength; $T_{S R A}\left(\alpha, \beta_{R}, F_{F A}(\psi)\right)$ ? noise temperature of a single-reflector antenna; $T_{T R A}\left(\alpha, \beta_{C}, F_{F A}(\theta)\right)$ ? noise temperature of a singlereflector antenna.

The power transmission coefficient taking into account the shadowing by the reflector design elements is determined from the expression

$$
\eta_{S}\left(\beta_{C}\right)=1-\left(\frac{\left(S_{S}+S_{S C}\left(\beta_{C}\right)\right)}{S_{R} V}\right),
$$

where $S_{S}$ is the area of shading of the reflector by the elements of the antenna structures; $S_{R}=0,25 \pi D_{R}{ }^{2}$ ? reflector area; $S_{S C}\left(\beta_{C}\right)$ ? the area of shading of the reflector aperture with an open screen is determined by the expression:

$$
\begin{aligned}
& S_{S C}\left(\beta_{C}\right)=\left[\frac{\sin \left(\beta_{C}\right) \sin \left(\psi_{0}\right)}{2 \sin \left(\varphi_{0}\right) \sin \left(\beta_{C}+\varphi_{0}+\psi_{0}\right)}+1\right] \times \\
& \times \frac{D_{C}{ }^{2} \sin \left(\beta_{C}\right) \sin \left(\psi_{0}\right) \arccos \left(\operatorname{ctg}\left(\varphi_{0}\right) \operatorname{tg}\left(\alpha_{\min }\right)\right)}{2 \sin \left(\varphi_{0}\right) \sin \left(\beta_{C}+\varphi_{0}+\psi_{0}\right)}
\end{aligned}
$$

For single-reflector antennas $S_{3 K}\left(\beta_{K}\right)=0$.

In figures 1 and 2 , the following designations are introduced for single-reflector and two-reflector antennas:

$\psi$ ? the angle between the maximum of the bottom of the axisymmetric feed and the direction in which the bottom of the feed is determined from the focus of the reflector;

$\theta, \varphi$ ? spherical angular coordinates (zenith and azimuthal angles);

$\beta_{R}, \beta_{C}$ ? the screening angle of the thermal noise of the Earth's antenna feed outside the reflector and the antenna feed outside the counter-reflector;

$R$ ? coordinate of the aperture of the reflector.

The power trans mission coefficient of the signal from the antenna feed to the reflector is determined by the expression:

$$
\eta_{R}=\frac{\int_{0}^{\psi_{0}}\left(F_{A F}(\psi)\right)^{2} \sin (\psi) d \psi}{2 \int_{0}^{\pi}\left(F_{A F}(\psi)\right)^{2} \sin (\psi) d \psi}+\frac{\int_{0}^{-\psi_{0}}\left(F_{A F}(\psi)\right)^{2} \sin (\psi) d \psi}{2 \int_{0}^{-\pi}\left(F_{A F}(\psi)\right)^{2} \sin (\psi) d \psi},
$$

where $F_{A F}(\psi)$ is the radiation pattern of the antenna feed or antenna feed and antenna counter-reflector.

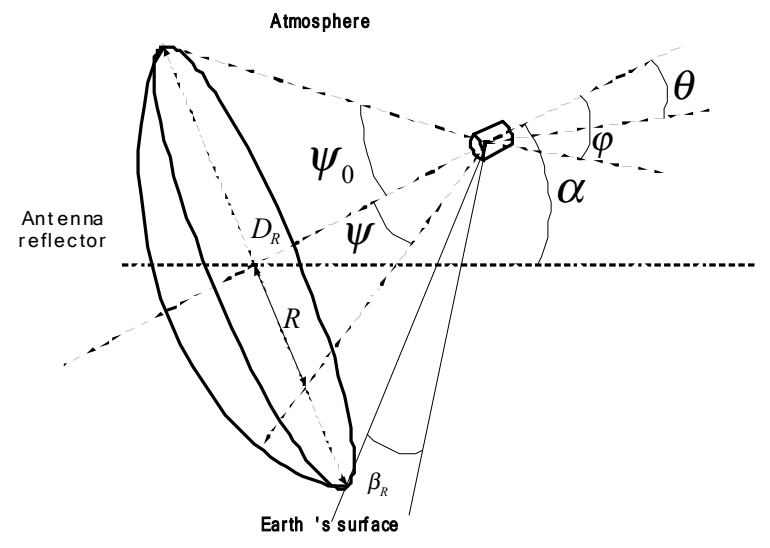

Figure 1. Reporting system of a single-reflector antenna

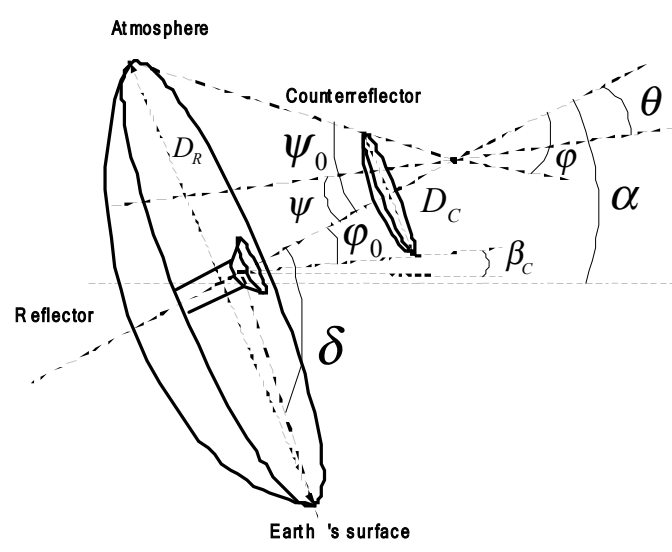

Figure 2. Reporting system of a two-reflector antenna

The power transmission coefficient of the signal from the antenna feed to the counter-reflector is determined by the expression: 


$$
\eta_{C}=\frac{\int_{0}^{\varphi_{0}}\left(F_{A F}(\theta)\right)^{2} \sin (\theta) d \theta}{2 \int_{0}^{\pi}\left(F_{A F}(\theta)\right)^{2} \sin (\theta) d \theta}+\frac{\int_{0}^{-\varphi_{0}}\left(F_{A F}(\theta)\right)^{2} \sin (\theta) d \theta}{2 \int_{0}^{-\pi}\left(F_{A F}(\theta)\right)^{2} \sin (\theta) d \theta}
$$

where $F_{A F}(\theta)$ is the radiation patterns of the two-reflector antenna feed.

The transmission coefficient for the power of the waveguide is given in the technical documentation for the antenna or is determined from the expression

$$
\eta_{W}=10^{\frac{\sum_{i=1}^{n} x_{i}}{10}}
$$

where $\mathrm{X}_{i}$ is the attenuation in the path of the element with index $i$; $n$ - the number of elements of the waveguide.

The coefficient of use of the surface of the reflector is determined by the expression:

$$
v=\frac{\left(\int_{0}^{1} F_{R}\left(R^{\prime}\right) R^{\prime} d R^{\prime}\right)^{2}}{\int_{0}^{1} F_{R}^{2}\left(R^{\prime}\right) R^{\prime} d R^{\prime}}+\frac{\left(\int_{0}^{-1} F_{R}\left(R^{\prime}\right) R^{\prime} d R^{\prime}\right)^{2}}{\int_{0}^{-1} F_{R}^{2}\left(R^{\prime}\right) R^{\prime} d R^{\prime}} .
$$

In expression (7),

$$
\begin{aligned}
& F_{R}\left(R^{\prime}\right)=\left(1+\cos \left(2 \arctan \left(R^{\prime} \tan \left(\frac{\psi_{0}}{2}\right)\right)\right)\right) \times \\
& \times \frac{F_{A F}\left(2 \arctan \left(R^{\prime} \tan \left(\frac{\psi_{0}}{2}\right)\right)\right)}{2}
\end{aligned}
$$

is the normalized field distribution in the aperture of the reflector, taking into account spatial attenuation on the way from the focus to the reflector; $R^{\prime}=\frac{2 R}{D_{P}}$ ? is the normalized coordinate of the point of the aperture of the reflector.

The radiation pattern of a single-reflector antenna feed is calculated from the expression

$$
\begin{aligned}
& F_{A F}(\psi)=\frac{1+\cos (\psi)}{4} \times \\
& \times\left[\frac{2 J_{1}\left(k R_{A F} \sin (\psi)\right)}{k R_{A F} \sin (\psi)}+\frac{8 J_{2}\left(k R_{A F} \sin (\psi)\right)}{\left(k R_{A F} \sin (\psi)\right)^{2}}\right]
\end{aligned}
$$

where $J_{1}\left(k R_{A F} \sin (\psi)\right), J_{2}\left(k R_{A F} \sin (\psi)\right)$ are the Bessel functions of the first and second order; $k=\frac{2 \pi}{\lambda}$ is the wave number; $R_{A F}$ is the radius of the antenna feed. To calculate the radiation pattern of the antenna feed of a two-reflector antenna in expression (8), a change is made $\psi$ to $\theta$.

The noise temperature of single-reflector antennas is determined from the expression

$$
\begin{aligned}
& T_{S R A}\left(\alpha, \beta_{R}, F_{F A}(\psi)\right)= \\
& =\left[T_{R}\left(\alpha, \beta_{R}, F_{F A}(\psi)\right)+\eta_{R} T_{A}(\alpha)\right] \eta_{W}+. \\
& +T_{0}\left(1-\eta_{W}\right)+T_{L N B}
\end{aligned}
$$

For two-reflector antennas expression

$$
\begin{aligned}
& T_{T R A}\left(\alpha, \beta_{C}, F_{F A}(\theta)\right)= \\
& =\left[T_{C}\left(\alpha, \beta_{C}, F_{F A}(\theta)\right)+\eta_{C} T_{R}\left(\alpha, 0, F_{F A}(\psi)\right)+\eta_{R} \eta_{C} T_{A}(\alpha)\right] \eta_{W}+ \\
& +T_{0}\left(1-\eta_{W}\right)+T_{L N B}
\end{aligned}
$$

The following notation is used in expressions (9-10):

$T_{R}\left(\alpha, \beta_{R}, F_{F A}(\psi)\right)$ ? noise temperature due to the reception by the antenna feed of the antenna or the antenna feed of the antenna and the counter-reflector of thermal radio emission outside the antenna reflector;

$T_{C}\left(\alpha, \beta_{C}, F_{F A}(\theta)\right)$ ? noise temperature due to the reception by the antenna feed of thermal radio emission outside the antenna's counter-reflector;

$T_{A}(\alpha)$ ? noise temperature of the antenna, due to the reception of thermal radio emission by the radiation pattern formed by the reflector and antenna elements;

$T_{0}$ ? absolute physical temperature of the environment;

$T_{L N B}$ ? noise temperature low-noise block downconverter.

In $[4,5]$, the need for increasing the accuracy of calculating noise temperature due to the antenna feed receiving thermal radio emission from the surrounding space by the method of fragmentation of the surrounding space developed by Professor Somov A.M. was shown. The expressions for the calculation are obtained taking into account the physical picture of receiving thermal radio emission and the method of fragmentation of the surrounding space:

$$
\begin{gathered}
T_{R}\left(\alpha, \beta_{R}, F_{A F}(\psi)\right)=\frac{\int_{\psi_{0}}^{\pi} T_{A S}(\alpha, \psi)\left(F_{A F}(\psi)\right)^{2} \sin (\psi) d \psi}{\int_{0}^{\pi}\left(F_{A F}(\psi)\right)^{2} \sin (\psi) d \psi}+ \\
+\frac{\int_{\left(\psi_{0}+\beta_{R}\right)}^{-\pi} T_{E S}(\alpha, \psi)\left(F_{A F}(\psi)\right)^{2} \sin (\psi) d \psi}{\int_{0}^{-\pi}\left(F_{A F}(\psi)\right)^{2} \sin (\psi) d \psi} \\
T_{C}\left(\alpha, \beta_{C}, F_{A F}(\theta)\right)=\frac{\int_{\varphi_{0}}^{\delta} T_{A S}(\alpha, \theta)\left(F_{A F}(\theta)\right)^{2} \sin (\theta) d \theta}{\int_{0}^{\pi}\left(F_{A F}(\theta)\right)^{2} \sin (\theta) d \theta}+ \\
+\frac{\int_{\left(\varphi_{0}+\beta_{C}\right)}^{-\delta} T_{E S}(\alpha, \theta)\left(F_{A F}(\theta)\right)^{2} \sin (\theta) d \theta}{\int_{0}^{-\pi}\left(F_{A F}(\theta)\right)^{2} \sin (\theta) d \theta}
\end{gathered}
$$

The following notation is used in expressions (11) and (12):

$T_{A S}(\alpha, \psi)$ and $T_{A S}(\alpha, \theta)$ is the effective noise temperature of the atmosphere;

$T_{E S}(\alpha, \psi)$ and $T_{E S}(\alpha, \theta)$ is the effective noise temperature of the Earth. The effective noise temperature of the Earth can $b \epsilon$ different and depends on the state of the earth's surface. The analysis of the antenna installation sites showed that the earth's surface in its noise characteristics is close to the "absolutely black" surface. Therefore, the effective noise temperature of the Earth is determined by the expression 


$$
T_{E S}(\alpha, \theta)=\left\{\begin{array}{l}
\frac{T_{0} \arccos \left(\frac{\operatorname{tg}(\alpha)}{\operatorname{tg}\left(\varphi_{0}\right)}\right)}{\pi}, \text { if } \alpha<\varphi_{0} \\
T_{0}, \text { if } \alpha>\varphi_{0}
\end{array} .\right.
$$

The effective noise temperature of the atmosphere is determined for dry, clear weather by the expression

$$
\begin{aligned}
& T_{A S}(\alpha, \theta)= \\
& =\left\{\begin{array}{l}
\frac{T_{\text {zenith }}}{\pi} \int_{0}^{\pi} \frac{d \varphi}{\left(\sin \left(\theta_{A}(\theta, \varphi)\right)+p\right)}, \text { if } 0<\theta<\alpha \\
\frac{T_{\text {zenith }}}{\pi} \int_{0}^{\operatorname{arcos}(-\operatorname{tg}(\alpha) \operatorname{ctg}(\theta))} \frac{d \varphi}{\left(\sin \left(\theta_{A}(\theta, \varphi)\right)+p\right)} \text {, if } \alpha \leq \theta \leq \pi-\alpha
\end{array}\right.
\end{aligned}
$$

where $\theta_{A}(\theta, \varphi)=\arcsin (\sin (\theta)[\sin (\alpha) \operatorname{ctg}(\theta)+\cos (\alpha) \cos (\varphi)])$; $T_{\text {zenith }}$ is the brightness noise temperature of the atmosphere in the zenith direction; $p$ is the coefficient of the relationship between the brightness noise temperatures of the atmosphere in the zenith direction and the horizon. The values $T_{\text {zenith }}$ and $p$ of and are constants for different frequencies and are given in table 1 [6].

Table 1

Values of the brightness noise temperature of the atmosphere in the zenith direction and the coefficient of the relationship of the brightness noise temperatures of the atmosphere in the zenith direction and the horizon

\begin{tabular}{|c|c|c|}
\hline Frequency, $\mathrm{GHz}$ & $T_{\text {zenith }},{ }^{\circ} \mathrm{K}$ & $p$ \\
\hline 4 & 2,9 & 0,028 \\
\hline 8 & 3,7 & 0,031 \\
\hline 12 & 4,5 & 0,032 \\
\hline 20 & 19 & 0,07 \\
\hline
\end{tabular}

For the calculation $T_{A S}(\alpha, \psi)$ and $T_{E S}(\alpha, \psi)$, the variables are replaced $\varphi_{0}$ by $\psi_{0}$ and $\theta=\pi-\psi$ in the expressions (13-14).

The Cassegrain classical scheme for constructing axisymmetric two-reflector antennas is the most common. The angle shown in Figure 2 for the classical Cassegrain scheme is determined from the expression

$$
\delta=\left\{\begin{array}{l}
\pi-\operatorname{arctg}\left[\frac{D_{R} \operatorname{tg}\left(\varphi_{0}\right) \operatorname{tg}\left(\psi_{0}\right)}{\left(D_{R}-D_{C}\right) \operatorname{tg}\left(\varphi_{0}\right)-D_{C} \operatorname{tg}\left(\psi_{0}\right)}\right] \text {,if }\left(D_{P}-D_{K}\right) \operatorname{tg}\left(\varphi_{0}\right)>D_{K} \operatorname{tg}\left(\psi_{0}\right) \\
\operatorname{arctg}\left[\frac{D_{R} \operatorname{tg}\left(\varphi_{0}\right) \operatorname{tg}\left(\psi_{0}\right)}{\left(D_{C}-D_{R}\right) \operatorname{tg}\left(\varphi_{0}\right)+D_{C} \operatorname{tg}\left(\psi_{0}\right)}\right], \text { if }\left(D_{P}-D_{K}\right) \operatorname{tg}\left(\varphi_{0}\right)<D_{K} \operatorname{tg}\left(\psi_{0}\right) \\
\frac{\pi}{2}, \text { if }\left(D_{R}-D_{C}\right) \operatorname{tg}\left(\varphi_{0}\right)=D_{C} \operatorname{tg}\left(\psi_{0}\right)
\end{array}\right.
$$

The noise temperature of the antenna is determined by the method of fragmentation from the expression

$$
\begin{aligned}
& T_{A}(\alpha)=\frac{\int_{0}^{\pi}(E(\theta))^{2} T_{A S}(\alpha, \theta) \sin (\theta) d \theta}{\int_{0}^{\pi}(E(\theta))^{2} \sin (\theta) d \theta}+ \\
& +\frac{\int_{0}^{-\pi}(E(\theta))^{2} T_{E S}(\alpha, \theta) \sin (\theta) d \theta}{\int_{0}^{-\pi}(E(\theta))^{2} \sin (\theta) d \theta}
\end{aligned}
$$

where $E(\theta)$ is the radiation patterns of the field strength formed by the reflector and antenna elements.

Calculation of the antenna pattern by field strength can $b \epsilon$ carried out by various methods (aperture, current, etc.). However, the study of Professor Somov A.M. showed that the accuracy of the calculation of noise temperature does not depend on the choice of method for calculating the antenna pattern [6]. Therefore, to calculate the antenna pattern, the aperture method with ten members of the approximation polynomial was chosen.

$$
\begin{aligned}
& E\left(\theta, F_{A F}(\psi)\right)=\frac{a_{0} \Lambda_{1}(\theta)+\frac{a_{1}}{2} \Lambda_{2}(\theta)+\frac{a_{2}}{3} \Lambda_{3}(\theta)+\frac{a_{3}}{4} \Lambda_{4}(\theta)+\frac{a_{4}}{5} \Lambda_{5}(\theta)}{a_{0}+\frac{a_{1}}{2}+\frac{a_{2}}{3}+\frac{a_{3}}{4}+\frac{a_{4}}{5}+\frac{a_{5}}{6}+\frac{a_{6}}{7}+\frac{a_{7}}{8}+\frac{a_{8}}{9}+\frac{a_{9}}{10}}+ \\
& +\frac{\frac{a_{5}}{6} \Lambda_{6}(\theta)+\frac{a_{6}}{7} \Lambda_{7}(\theta)+\frac{a_{7}}{8} \Lambda_{8}(\theta)+\frac{a_{8}}{9} \Lambda_{9}(\theta)+\frac{a_{9}}{10} \Lambda_{10}(\theta)}{a_{0}+\frac{a_{1}}{2}+\frac{a_{2}}{3}+\frac{a_{3}}{4}+\frac{a_{4}}{5}+\frac{a_{5}}{6}+\frac{a_{6}}{7}+\frac{a_{7}}{8}+\frac{a_{8}}{9}+\frac{a_{9}}{10}}
\end{aligned}
$$

where $\Lambda_{1}(\theta), \Lambda_{2}(\theta), \ldots, \Lambda_{10}(\theta)$ are the lambda function of the first, second, ..., tenth order. The lambda function of order $n$ is determined by the well-known expression:

$$
\Lambda_{n}(\theta)=\frac{2^{n} n ! J_{n}\left(k \frac{D_{P}}{2} \sin (\theta)\right)}{\left(k \frac{D_{P}}{2} \sin (\theta)\right)^{n}},
$$

where $J_{n}\left(0.5 k D_{R} \sin (\theta)\right)$ is the Bessel function of order $\mathrm{n}$. The coefficients $a_{0}, a_{1}, \ldots, a_{9}$ were determined by the iterative method. The system of equations obtained by the author and the solution of the resulting system of equations is not given because of the bulkiness.

The depth of the open conical screen on the reflector (Figure $3)$ is determined from the expression

$$
R_{R}(\tau)=\frac{D_{R} \sin \left(\beta_{R}\right)}{2 \sin \left(\psi_{0}\right) \sin \left(\psi_{0}+\beta_{R}+\tau\right)} ;
$$

the length of the perimeter of the screen along the edge of the reflector

$$
L_{R}=\left\{\begin{array}{l}
\frac{D_{R}}{2}\left(\pi+2 \arcsin \left(\frac{\operatorname{tg}\left(\alpha_{\text {max }}\right)}{\operatorname{tg}\left(\psi_{0}\right)}\right)\right), \text { if } 0<\alpha_{\text {max }}<\psi_{0} . \\
\pi D_{R}, \text { if } \alpha_{\text {max }} \geq \psi_{0}
\end{array}\right.
$$

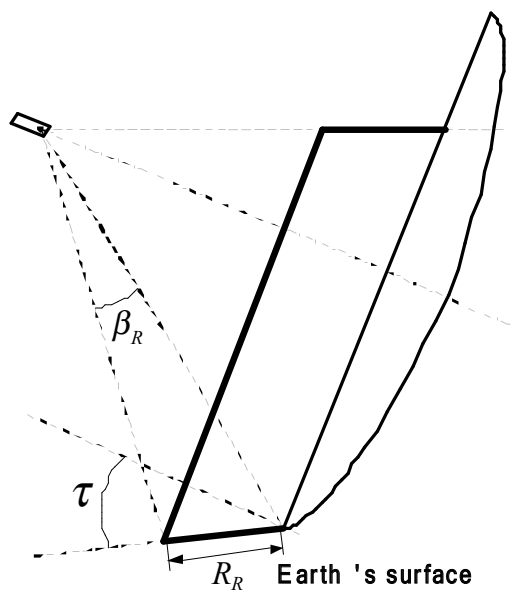


The depth of the open conical screen on the counter-reflector (Figure 4) is determined from the expression

$$
R_{C}=\frac{D_{C} \sin \left(\beta_{C}\right)}{2 \sin \left(\varphi_{0}\right) \sin \left(\beta_{C}+\varphi_{0}+\psi_{0}\right)},
$$

the length of the screen perimeter on the counter-reflector

$$
L_{C}=D_{C} \arccos \left(\operatorname{ctg}\left(\varphi_{0}\right) \operatorname{tg}\left(\alpha_{\text {min }}\right)\right) \text {. }
$$

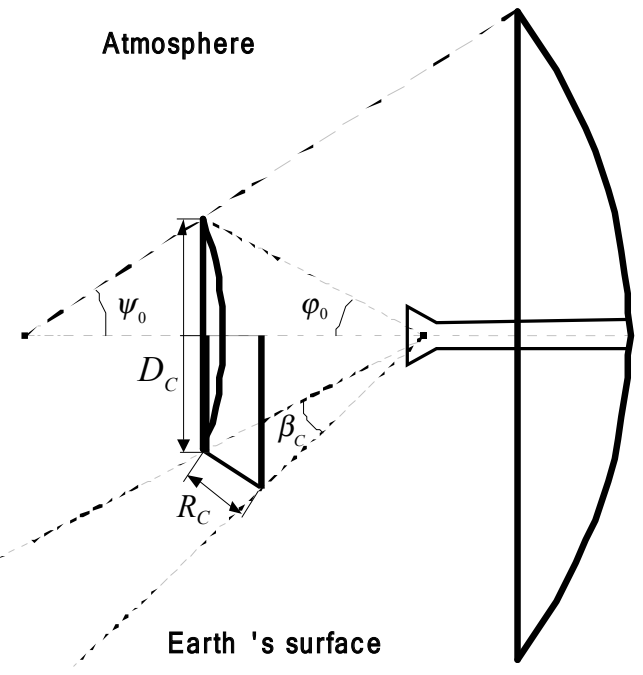

Figure 4. Two-mirror antenna with an open conical screen on the counter-reflector at a zero angle to the horizon, side view

This technique has been tested on two single-reflector antennas, with reflector diameters of 2 and 5 meters, and five two-reflector antennas. The results of theoretical calculations and measurements of increasing the antenna gain-to-noisetemperature $(\Delta G / T)$ of the antennas are shown in table 2 .

Table 2

The calculated and measured values of increasing the antenna gain-to-noise-temperature $(\Delta G / T)$

$\begin{array}{ccc}\text { Diameter reflector, } m & \begin{array}{r}\text { Estimated value } \\ (\Delta G / T), д Б / К\end{array} & \begin{array}{c}\text { Measured value, } \\ (\Delta G / T) д Б / К\end{array} \\ 2 & 1 & 1 \\ 5 & 0.6 & 0.5 \\ 7 & 0.8 & 0.9 \\ 7 & 0.9 & 0.8 \\ 9 & 1 & 1 \\ 12 & 0.8 & 0.8 \\ 16 & 0.6 & 0.5\end{array}$

When developing the methodology, patents and computer programs registered in the Russian Federation were used $[7 ; 8 ; 9$; $10 ; 11]$.

\section{Conclusion}

The developed technique is universal for axisymmetric reflector antennas of satellite communications earth stations. Using the presented methodology in practice, it is possible to increase the SNR of the received signals to $1.5 \mathrm{~dB}$ from the satellites of the repeaters located in the geostationary orbit at the antenna output. Parts of this technique have been successfully used in practice to increase the SNR of received signals. The us of open screens on the antenna reflector allows you to increase the SNR of the received signals by $1.5 \mathrm{~dB}$. The use of open screens on the reflector of reflector antennas allows you to increase the SNR of the received signals by $1 \mathrm{~dB}$. The use of antenna feeds with an asymmetric radiation pattern for axisymmetric reflector antennas can increase the SNR of the received signals by $0.8 \mathrm{~dB}$.

\section{References}

1. Trevor S. Bird. (2015). Fundamentals of Aperture Antennas ana Arrays: From Theory to Design, Fabrication and Testing. Wiley Telecom.448 p.

2. Thomas A. Milligan. (2005). Modern Antenna Design, 2nc Edition. Wiley-IEEE Press. 632 p. ISBN: 978-0-471-45776-3.

3. Somov A.M. Titovets P.A. (2018). Method for increasing the noise quality of earth stations of satellite communication systems due tc an feed antenna with an asymmetric directional diagram. Trudy NIIR. No.1,pp. 16-23. (in Russian)

4. Somov A.M. Titovets P.A. (2017). Earth stations for satellite communications with open screen on the single-dish reflector antenna system. Trudy NIIR. No. 4, pp. 23-29. (in Russian)

5. Somov A.M. Titovets P.A. (2017). Method for increasing the noise quality of earth stations of satellite communication due to an oper conical screen on a counter-reflector. Trudy NIIR. No. 3, pp. 52-60. (in Russian)

6. Somov A.M. Method fragmentation for calculating the noist temperature of antennas. Moscow. Gorjachaja linija-Telekom, 2009. 208 p. (in Russian)

7. Patent Russia, No 2420840, 10.06.2011.

8. Patent Russia, № $2420841,10.06 .2011$.

9. Patent Russia, № 2426203, 10.08.2011.

10. Somov A.S., Vorontsov A.P., Titovets P.A. Program for calculating the efficiency of open screens along the perimeter of the reflector antenna reflector. No. 2019663623. 2019. (in Russian)

11. Somov A.S., Vorontsov A.P., Titovets P.A. Program for calculating a two-reflector antenna with unclosed anti-noise screens for a terrestrial satellite communication station. The Certificate on Officia Registration of the Computer Program. No. 2019663787. 2019 (in Russian) 


\title{
МЕТОДИКА ПОВЫШЕНИЯ ШУМОВОЙ ДОБРОТНОСТИ ОСЕСИММЕТРИЧНЫХ ЗЕРКАЛЬНЫХ АНТЕНН ЗЕМНЫХ СТАНЦИЙ СПУТНИКОВОЙ СВЯЗИ
}

\author{
Титовец Павел Александрович, Московский технический университет связи и информатики, Москва, Россия,
} paveltitovec@mail.ru

\begin{abstract}
Аннотация
Спутниковая связь для многих малозаселенных, труднодоступных и удаленных территорий, особенно Арктических районов и Крайнего севера является основным видом связи. При организации связи требуется принимать сигналы с максимально возможным отношением сигнал/шум. В земных станциях спутниковой связи, в основном, применяются осесимметричные зеркальные антенны. На указанных территориях угол наклона антенн к горизонту не превышает 20 градусов. Существуют проблемы при приеме сигналов при углах наклона осесимметричных зеркальных антенн к горизонту, не превышающих 20 градусов, земными станциями спутниковой связи. Эти проблемы связаны с отношением сигнал/шум на выходе антенн. При таких углах наклона зеркальных антенн к горизонту тепловое радиоизлучение поверхности Земли оказывает существенное негативное влияние на принимаемые сигналы. Это радиоизлучение повышает уровень шумов и снижает отношение сигнал/шум на выходе антенны. Для снижения теплового радиоизлучения, принимаемого зеркальными антеннами от поверхности Земли, и повышения отношения сигнал/шум на выходе антенн разработана методика повышения шумовой добротности. Эта методика состоит из трех самостоятельных методов повышения шумовой добротности, которые могут использоваться отдельно. Для удобства выбора из существующих методов повышения шумовой добротности в методике учтены особенности применимости этих методов для конкретных антенн. Описан разработанный метод расчета шумовой добротности, позволяющий теоретически оценить изменения шумовой добротности за счет незамкнутых экранов на рефлекторе и контррефлекторе, а также за счет применения облучателей с несимметричной диаграммой направленности.
\end{abstract}

Ключевые слова: спутниковая связь, земные станции, осесимметричные зеркальные антенны, шумовая добротность, методика повышения отношения сигнал шум.

\section{Литература}

I. Trevor S. Bird. Fundamentals of Aperture Antennas and Arrays: From Theory to Design, Fabrication and Testing. Wiley Telecom, 2015. $448 \mathrm{p}$.

2. Thomas A. Milligan. Modern Antenna Design, 2nd Edition. Wiley-IEEE Press, 2005. 632 p. ISBN: 978-0-47I-45776-3.

3. Сомов А.М., Титовец П.А. Способ повышения шумовой добротности земных станций систем спутниковой связи за счет облучателя с несимметричной диаграммой направленности Труды НИИР. 2018. Вып. №І. С. 16-23.

4. Сомов А.М., Титовец П.А. Земные станций спутниковой связи с незамкнутым экраном на рефлекторе однозеркальной антенной системы // Труды НИИР. 2017. Вып. №4. С. 23-29.

5. Сомов А.М., Титовец П.А. Способ увеличения шумовой добротности земных станций спутниковой связи за счет незамкнутого конического экрана на контррефлекторе // Труды НИИР. 2017. Вып. 3. С. 52-60.

6. Сомов А.М. Метод фрагментации для расчета шумовой температуры антенн. - М.: Горячая линия-Телеком, 2009. - 208 с.

7. Сомов А.М., Титовец П.А. Осесимметричная зеркальная антенна // Патент России №2420840. 20I I. Бюл. № 16.

8. Сомов А.М., Титовец П.А. Осесимметричная двухзеркальная антенна // Патент России №242084I. 20II. Бюл. № 16.

9. Сомов А М., Титовеи П.А. Осесимметричная зеркальная антенна (варианты) // Патент России №2426203. 201 I. Бюл. № 22.

10. Сомов А.М., Ворониов А.П., Титовеи П.А. Программа расчета эффективности незамкнутых экранов по периметру рефлектора зеркальной антенны // Свидетельство о государственной регистрации программы для ЭВМ № 2019663623 от 21.10.2019.

II. Сомов А.М., Воронцов А.П., Титовеи П.А. Программа расчета двухзеркальной антенны с незамкнутыми противошумовыми экранами для земной станции спутниковой связи // Свидетельство о государственной регистрации программы для ЭВМ № 2019663787 от 23.10 .2019 .

Информация об авторе:

Титовеи, Павел Александрович, ведущий инженер научно-исследовательского отдела Московского технического университета связи и информатики, Москва, Россия 